\title{
Screening test for rheumatic diseases: a combined enzyme immunoassay of rheumatoid factors and antibodies to DNA and extractable nuclear antigens
}

\author{
P KURKI,${ }^{*} \dagger$ MARIANNE GRIPENBERG, $\dagger$ P PARTANEN, $\dagger$ T HELVE $\ddagger$ \\ From the *Department of Pathology, University of Helsinki; †Labsystems Research Laboratories, Helsinki, and \\ the $\ddagger$ Department of Medicine, University Central Hospital of Helsinki, Helsinki, Finland
}

SUMMARY Three hundred and one sera from patients with rheumatic and other diseases were investigated using a simple enzyme immunoassay for screening of rheumatoid factors and antinuclear antibodies. The assay had a sensitivity of $77 \%$ for systemic lupus erythematosus, $90 \%$ for the primary sicca syndrome, and $89 \%$ for rheumatoid arthritis. Only $13 \%$ of sera from patients with chronic non-rheumatic diseases were positive. The test was further evaluated in a group of patients with suspected rheumatic disease who were followed up for six to 12 months. The test was positive in 16 of 17 sera from patients with connective tissue diseases but in only seven of 36 sera (19\%) from patients with non-inflammatory joint diseases. None of the four patients with reactive arthritis was positive by this test. The sensitivity of the assay was comparable with that of the agglutination and immunofluorescence tests for rheumatoid factors and antinuclear factors. For the screening of rheumatoid factor and antinuclear antibodies this kind of test panel offers a simple alternative to the conventional tests for small clinical laboratories and for those in which the autoantibody tests could be automated, as the assay can be performed in one working day and only one dilution of serum is needed to obtain a quantitative result.

The most useful autoantibodies in the initial screening for rheumatoid arthritis, systemic lupus erythematosus, and related rheumatic diseases are rheumatoid factors and antinuclear antibodies. ${ }^{12}$ These antibodies are generally determined using agglutination and indirect immunofluorescence tests, which have several drawbacks. First, positive sera must be titrated to obtain a semiquantitative result because low titres of these antibodies are known to occur in several non-rheumatic diseases. ${ }^{134}$ In addition, the standardisation of these tests has been very difficult $^{5-7}$ and automation has not been successful. Many of the drawbacks of the conventional autoantibody tests could be avoided by using quantitative immunoenzymatic assays. $^{8}$

\section{Material and methods}

Sera from 74 patients with systemic lupus erythematosus (mean age 39, range 18-73) who participated in a follow up study, sera from 52 patients with rheumatoid arthritis (mean age 59, range 20-87), and 10 patients with primary sicca syndrome (mean age 61 years, range 37-78) were investigated. Patients with systemic lupus erythematosus fulfilled at least four of the American Rheumatism Association preliminary criteria for the classification of systemic lupus erythematosus. ${ }^{9}$ The patients with rheumatoid arthritis had definite or classical rheumatoid arthritis according to the American Rheumatism Association criteria. ${ }^{10}$ Patients with primary Sjögren's syndrome had clinical signs of a sicca syndrome, a positive Schirmer's test or staining of the conjunctiva by Rose Bengal or both, and typical findings in the sialography of the parotid gland or in the salivary gland biopsy specimen, or both.

We also tested sera from 21 patients with thyroid diseases (10 with autoimmune thyroiditis, three with Basedow's disease, three with subacute thyroiditis, one with thyrotoxicosis and nodular goitre, and four with non-toxic goitre (mean age 45 years, range 23-75); 29 patients with hypertension or coronary artery disease, or a combination (mean age 59 years, range 27-78); and 20 patients with alcoholic liver 
injury (10 with cirrhosis, eight with pure alcoholic fatty liver, two with alcoholic hepatitis). Sera from 20 patients with non-inflammatory joint diseases were also investigated (18 patients had osteoarthritis, two undefined arthralgias). Furthermore, sera from 91 blood donors were tested for antibodies to extractable nuclear antigen.

The value of the new test in the screening of rheumatic diseases was further tested in sera from 75 patients who were attending the outpatient clinic of the Helsinki University Central Hospital. The serum sample was taken on the first visit to the clinic. The clinical diagnosis was recorded after six to 12 months' follow up. The diagnostic criteria for rheumatic diseases in this group were similar to those described above, but sometimes a clinical "working" diagnosis only could be made.

\section{ENZYME IMMUNOASSAY \\ Antigen preparations}

Human IgG (Sigma Chemical Company St Louis, Missouri, USA) was used at a concentration of $5 \mu \mathrm{g} / \mathrm{ml}$ and denatured DNA (calf thymus DNA type $\mathrm{I}$, Sigma) at $1 \mu \mathrm{g} / \mathrm{ml}$ for the coating of the polystyrene solid phase. These antigen concentrations were chosen on the basis of previous studies. ${ }^{11}{ }^{12}$ The antigens were dissolved in phosphate buffered saline (PBS), $\mathrm{pH}$ 7.2. The DNA was rendered single stranded (ss) by heating for 10 minutes at $100^{\circ} \mathrm{C}$ followed by rapid cooling.

The saline soluble antigens of rabbit thymus were purified from a powder of acetone extract of the tissue (Pel-Freez Biologicals, Rogers, Arizona, USA) using the method of White et al. ${ }^{13}$ The acetone powder was extracted with PBS (60 mg powder/ml PBS) for four hours at $4^{\circ} \mathrm{C}$. The suspension was centrifuged at $16000 \mathrm{~g}$ for 20 minutes. Ammonium sulphate was added to the supernatant up to $25 \%$ saturation. The supernatant was collected after centrifugation at $16000 \mathrm{~g}$ for 30 minutes. The ammonium sulphate saturation was increased up to $60 \%$ and the precipitated material was collected by centrifugation at $16000 \mathrm{~g}$ for 30 minutes. The precipitate was dissolved in $40 \mathrm{ml} 10 \mathrm{mM}$ sodium phosphate $(\mathrm{pH} 7 \cdot 3$ ) with $50 \mathrm{mM}$ sodium chloride and dialysed overnight against this buffer. Dialysate $(10 \mathrm{ml})$ was then applied to a $1.2 \times 24 \mathrm{~cm}$ column of DEAE-Sepharose CL-6B (Pharmacia, Uppsala, Sweden). The column was washed with the dialysis buffer until no protein was eluted. The antigenic preparation was obtained by eluting the column with $10 \mathrm{mM}$ sodium phosphate, pH $7 \cdot 3$, with $500 \mathrm{mM}$ sodium chloride. The pooled eluate contained $1 \mathrm{mg}$ protein $/ \mathrm{ml}$ and was dialysed overnight against PBS containing $0.01 \%$ sodium nitrate. The other fractions obtained during this purification procedure were dialysed against PBS and adjusted to the same protein concentration. The polypeptide contents of these fractions were compared by sodium dodecyl sulphate-polyacrylamide gel electrophoresis ${ }^{14}$ and autoantigens by immunoblotting. ${ }^{15}$ The fractions were tested with 10 patient sera using antigen concentrations of 50,25 , $12 \cdot 5$, and $6 \cdot 25 \mu \mathrm{g} / \mathrm{ml}$ PBS.

\section{Immobilisation}

We used two types of polystyrene cuvettes: $1 \times 8$ well Microstrips (Eflab, Helsinki, Finland) and cuvette blocks (nine cuvettes in a block) (Labsystems, Helsinki, Finland) in this solid phase enzyme immunoassay. The enzyme immunoassay procedure was the same for all three types of antibodies.

(1) The test sera were diluted 1/80 in PBS containing $0.05 \%$ Tween 20 (PBS-T). The sera were incubated in both the coated wells of the Microstrips or the cuvettes for two hours at $37^{\circ} \mathrm{C}$.

(2) The alkaline phosphatase labelled heavy chain specific swine antibodies (Orion Diagnostica, Espoo, Finland) to human IgG (ss-DNA, and extractable nuclear antigen antibodies) and to human IgM (rheumatoid factors) were diluted 1/500 in PBS-T and incubated for two hours at $37^{\circ} \mathrm{C}$.

(3) The enzyme specific substrate P-nitrophenyl phosphate disodium (Sigma 104 phosphatase substrate) was dissolved in $100 \mathrm{mM}$ carbonate buffer, $\mathrm{pH}$ $9 \cdot 7$, containing $1 \mathrm{mM} \mathrm{MgCl}$. The solution ( $1 \mathrm{mg}$ substrate $/ 1 \mathrm{ml}$ buffer) was incubated for 30 minutes a $37^{\circ} \mathrm{C}$.

The absorbance of the Microstrip wells was measured using a Multiskan 8-channel photometer for conventional microtitration plates (Eflab) and that of the cuvettes by the 9-channel FP-901 Chemistry Analyzer (Labstems) using a wavelength of $405 \mathrm{~nm}$.

The relevant autoantigens were concentrated in the extractable nuclear antigen fraction precipitated by $60 \%$ ammonium sulphate and eluted from a DEAE Sepharose column by $0.5 \mathrm{M}$ saline (table 1 ). This material contained several polypeptides of which only a few reacted with human antibodies (figure). There was a significant difference between extractable nuclear antigen negative and positive sera (as determined by the standard immunodiffusion test) using the antigen concentration of $20 \mu \mathrm{g} / \mathrm{ml}$ in enzyme immunoassay $(p<0.001)$. Furthermore, those sera containing anti-Sjögen's syndrome B, anti-Sm, or anti-ribonucleoprotein had a higher anti-extractable nuclear antigen binding in enzyme immunoassay than the sera precipitating unidentified extractable nuclear antigen antigens in the immunodiffusion test.

Rheumatoid factors were also determined by latex agglutination (Latex-RF, Behringwerke, Marburg, Federal Republic of Germany) and by sheep red cell agglutination (Cellognost-RF, Behringwerke). Anti- 
Table 1 Enrichment of autoantigens in different fractions of rabbit thymus extract

\begin{tabular}{|c|c|c|c|c|}
\hline \multirow[b]{2}{*}{ Sera* } & \multicolumn{4}{|c|}{ Fraction $\dagger$} \\
\hline & $\bar{A}$ & B & $C$ & $D$ \\
\hline \multicolumn{5}{|c|}{ Extractable nuclear antigen positive: } \\
\hline 1 & 0.450 & 0.340 & 0.830 & 0.090 \\
\hline 2 & 0.190 & 0.285 & 0.450 & 0.530 \\
\hline 3 & 0.210 & 0.125 & 0.420 & 0.060 \\
\hline 4 & $0 \cdot 180$ & 0.305 & 0.410 & 0.290 \\
\hline \multicolumn{5}{|c|}{ Extractable nuclear antigen negative: } \\
\hline 5 & 0.160 & 0.255 & $0 \cdot 130$ & 0.135 \\
\hline 6 & $0 \cdot 130$ & 0.260 & $0 \cdot 175$ & 0.120 \\
\hline 7 & 0.095 & 0.210 & $0 \cdot 125$ & $0 \cdot 125$ \\
\hline 8 & 0.090 & $0 \cdot 175$ & 0.115 & $0 \cdot 170$ \\
\hline 9 & 0.130 & 0.215 & $0 \cdot 140$ & $0 \cdot 130$ \\
\hline 10 & 0.175 & 0.170 & 0.180 & 0.180 \\
\hline
\end{tabular}

* Four sera were positive for extractable nuclear antigen by double immunodiffusion technique and six sera were negative. †Fraction (A) was obtained from the saline extract of rabbit thymus by $25 \%$ ammonium sulphate precipitation. Fractions (B) and (C) were obtained by $60 \%$ ammonium sulphate precipitation and ion exchange chromatography followed by elution with $50 \mathrm{mM}$ or $500 \mathrm{mM}$ sodium chloride, respectively. (D) contains antigens that were soluble in $60 \%$ ammonium sulphate.

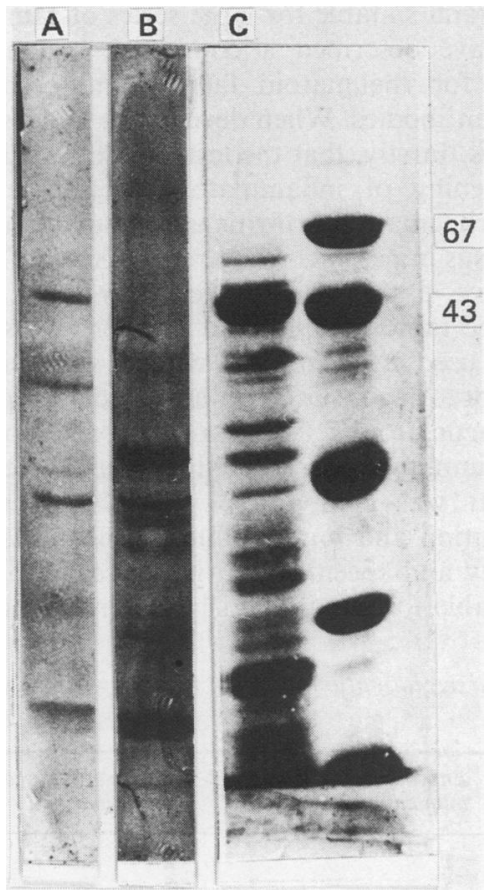

Figure Immunoblotting analysis of extractable nuclear antigen preparation for two sera containing Sm-and ribonuclear protein antibodies (lane B) and anti-Sjögen's syndrome B (lane A). Sodium dodecyl sulphate polyacrylamide gel electrophoresis of the extractable nuclear antigen preparation (lane $C$ ) and molecular weight markers are seen on the right hand side. nuclear antibodies were assayed by indirect immunofluorescence technique using cryostat sections of rat liver fixed in ethanol as antigen. The initial dilution of the test serum was $1 / 10$. Antibodies against the saline extract of rabbit thymus were assayed using double immunodiffusion. ${ }^{16}$

\section{Results}

\section{REFERENCE SERUM AND THE EXPRESSION OF} THE RESULTS

In the preliminary experiments we noticed an interassay variation of up to $24 \%$ (DNA), $39 \%$ (extractable nuclear antigen), and $27 \%$ (IgG) in the absorbance values of enzyme immunoassay positive sera. On the other hand, the variation within each individual assay could be avoided by using triplicate samples of each test serum. To diminish the interassay variation we chose a reference serum from a patient with systemic lupus erythematosus. The serum was positive in the immunofluorescence test for antinuclear antibodies (titre $1 / 80$ ) and in the latex agglutination test for rheumatoid factors. This serum also contained anti-ribonucleoprotein (anti-RNP) antibodies as judged by the immunodiffusion test. The results of the rheumatoid factor-antinuclear antibodiesenzyme immunoassay were then expressed in relation to this positive reference serum which was included in every run. The absorbance values obtained with the individual antigens were calculated as percentage of the respective values obtained with the reference serum and expressed as enzyme immunoassay units (EIU). ${ }^{17}$

\section{AUTOANTIBODIES TESTED BY RHEUMATOID \\ FACTOR - ANTINUCLEAR ANTIBODIES - ENZYME IMMUNOASSAY}

The reference values for the rheumatoid factorantinuclear antibodies-enzyme immunoassay were obtained by studying 50 sera from patients with nonrheumatic diseases (thyroid and coronary artery diseases). The mean ( +2 standard deviations) was 47 EIU for anti-ss DNA, 89 EIU for anti-extractable nuclear antigen, and 82 EIU for anti-IgG. These values were then regarded as the upper limits of the "normal" in the rheumatoid factor-antinuclear antibodies-enzyme immunoassay, except in the antiIgG enzyme immunoassay where the value was set to 120 EIU. The absorbance value corresponding to the upper limit of normal was about 0.500 for anti-ss DNA, $\mathbf{0} \cdot 120$ for anti-extractable nuclear antigen, and 0.450 for anti-IgG. These values were obtained from the assays carried out in Microstrips. This assay was also performed using larger polystyrene cuvette blocks (Labsystems) and 247 serum samples. The results were similar in all patient groups. The preva- 
Table 2 Autoantibody profiles by rheumatoid factor-antinuclear antibodies-enzyme immunoassay of sera from patients with inflammatory disease and from other patients

\begin{tabular}{|c|c|c|c|c|}
\hline \multirow[b]{2}{*}{ Diagnosis } & \multirow[b]{2}{*}{ No of patients } & \multicolumn{3}{|c|}{ Percent positive for antibodies against } \\
\hline & & $\begin{array}{l}\text { Single stranded } \\
D N A\end{array}$ & $\begin{array}{l}\text { Extractable nuclear } \\
\text { antigen }\end{array}$ & $\operatorname{Ig} G$ \\
\hline $\begin{array}{l}\text { Systemic lupus erythematosus } \\
\text { Sicca syndrome } \\
\text { Rheumatoid arthritis } \\
\text { Non-inflammatory joint diseases } \\
\text { Healthy blood donors } \\
\text { Other patients* }\end{array}$ & $\begin{array}{l}74 \\
10 \\
52 \\
20 \\
91 \\
70\end{array}$ & $\begin{array}{r}59 \\
40 \\
19 \\
5 \\
0 \\
6\end{array}$ & $\begin{array}{r}32 \\
30 \\
12 \\
5 \\
0 \\
3\end{array}$ & $\begin{array}{r}35 \\
60 \\
88 \\
25 \\
1 \\
6\end{array}$ \\
\hline
\end{tabular}

*Those with thyroiditis, hypertension, coronary artery or alcoholic liver disease.

Table 3 Diagnostic sensitivity and specificity of rheumatoid factor-antinuclear antibodies-enzyme immunoassay

\begin{tabular}{lll}
\hline & Positive (\%) & Negative (\%) \\
\hline Systemic lupus erythematosus & 77 & 23 \\
Sicca syndrome & 90 & 10 \\
Rheumatoid arthritis & 88 & 12 \\
Healthy blood donors & 1 & 99 \\
Controls & 13 & 87 \\
\hline
\end{tabular}

*Most of the patients were in remission.

lence of the positive results in each individual assay in sera from patients with rheumatic and non-rheumatic diseases is shown in table 2 . The assay was regarded as positive if the test serum contained an increased amount of at least one type of autoantibody (table 3).

Sera from 75 patients attending the outpatient clinic of Helsinki University Central Hospital because of a suspected rheumatic disease were investigated with the rheumatoid factor-antinuclear antibodiesenzyme immunoassay. The serum samples from these patients were also assayed for rheumatoid factors and antinuclear antibodies using conventional immunofluorescence and agglutination techniques. The patients were followed up for six to 12 months. The results of the assay and the comparison with those obtained by the conventional tests are shown in table 4. All sera containing more than one type of antibody were from patients with connective tissue disease.

\section{Discussion}

The increasing demand for diagnostic tests in rheumatology may be difficult to satisfy unless the laboratories are capable of using methods that are cost effective and suitable for large series of samples.

We have described a combined enzyme immunoassay for rheumatoid factors and certain antinuclear antibodies. When developing this test we had two goals. Firstly, that the test should be suitable for the screening of inflammatory rheumatic disease, such as rheumatoid arthritis and systemic lupus erythematosus in patients who are suspected of having a connective tissue disease. Secondly, that the test should be rapid, simple, and inexpensive, so that it could be used in laboratories with no specialist equipment for diagnostic immunological procedures. The rheumatoid factor-antinuclear antibodiesenzyme immunoassay seemed to meet these requirements. It was comparable with the conventional agglutination and immunofluorescence tests in both sensitivity and specificity. It is also easy to perform and suitable for handling of large series of samples.

Table 4 Comparison of enzyme immunoassay with immunofluorescence and agglutination tests for screening for rheumatic disease

\begin{tabular}{|c|c|c|c|c|}
\hline Clinical diagnosis & $\begin{array}{l}\text { No of } \\
\text { patients }\end{array}$ & $\begin{array}{l}\text { Enzyme } \\
\text { immunoassay } \Gamma^{*}\end{array}$ & $\begin{array}{l}\text { Enzyme } \\
\text { immunoassay II }\end{array}$ & $\begin{array}{l}\text { Immunofluorescence } † \text { and } \\
\text { agglutinationt }\end{array}$ \\
\hline $\begin{array}{l}\text { Systemic lupus erythematosus } \\
\text { Sicca syndrome } \\
\text { Rheumatoid arthritis } \\
\text { Reactive arthritis } \\
\text { Non-inflammatory joint diseases } \\
\text { Other diseases }\end{array}$ & $\begin{array}{r}2 \\
5 \\
10 \\
4 \\
36 \\
18\end{array}$ & $\begin{array}{l}2 \\
5 \\
9 \\
0 \\
7 \\
1\end{array}$ & $\begin{array}{r}2 \\
5 \\
10 \\
0 \\
7 \\
1\end{array}$ & $\begin{array}{l}2 \\
5 \\
8 \\
0 \\
9 \\
2 / 6\end{array}$ \\
\hline
\end{tabular}

*EIA I was carried out by using $1 \times 8$ well polystyrene Microstrips and EIA II by using $1 \times 9$ well polystyrene cuvette blocks.

tThe test was performed using rat liver as substrate with an initial serum dilution of $1 / 10$.

fThe test was performed using two commercial kits based on latex and red blood cell agglutination. The initial serum dilution was $1 / 20$. The result was recorded as positive if either of the tests was positive. 
We used a solid phase enzyme immunoassay because of its specificity and easy automation. The antigens IgG, DNA, and extractable nuclear antigen for the assay were selected because they are the main targets for autoantibodies in rheumatoid arthritis and systemic lupus erythematosus. There are many reports of immunoenzymatic assays for autoantibodies against these antigens. ${ }^{8}$ Enzyme immunoassay for rheumatoid factors of IgM class shows a good correlation with agglutination tests, especially the Waaler-Rose test. ${ }^{13}$ Single stranded DNA antibodies of IgG class assayed by enzyme immunoassay are found in $65-83 \%$ of patients with systemic lupus erythematosus and $35-48 \%$ of those with rheumatoid arthritis. ${ }^{1218}$ In a previous study $94 \%$ of sera positive to antinuclear antibodies were also positive to anti-ss DNA by enzyme immunoassay. ${ }^{12}$ In addition, about $60 \%$ of the patients with a negative result in the fluorescence antinuclear antibody test had antibodies to single stranded DNA. ${ }^{19}$ While these antibodies are also known to occur in several other diseases, ${ }^{56}$ high concentrations of antibodies of IgG class are rare in non-rheumatic diseases.

The saline extract of rabbit thymus contains several important autoantigens, generally referred to as extractable nuclear antigens. ${ }^{20}$ Some fluorescent antinuclear antibody negative patients with systemic lupus erythematosus have circulating antibodies to extractable nuclear antigen. ${ }^{19}$ The extract has been used as an antigen in enzyme immunoassay without any further purification. ${ }^{2122}$ On the other hand, specific extractable nuclear antigen antibodies have been determined by enzyme immunoassay using affinity purified antigens. ${ }^{23-25}$ It is obvious that some tests for individual extractable nuclear antigen antibodies will be able to use monoclonal antibodies currently produced in many laboratories, but the purification of several important extractable nuclear antigen on a large scale and at the same time is laborious. We therefore enriched the relevant autoantigens in the protein mixture by salt fractionation and ion exchange chromatography. The results of the antiextractable nuclear antigen enzyme immunoassay and the standard immunodiffusion test showed a good correlation.

Rheumatoid factor-antinuclear antibodies-enzyme immunoassay gives quantitative results without requiring titration of the test sera. The cut off points were high to avoid "false" positive results. Of course, this can also diminish the sensitivity of test, but the different autoantibody systems used in the test seemed to complement each other so that the overall sensitivity was comparable with that of conventional agglutination and immunofluorescence tests. ${ }^{249}$ The value of this test for screening diseases, such as rheu- matoid arthritis and systemic lupus erythematosus will, of course, depend on the population studied. The number of false positive results in this test is acceptable if the patients have already been selected on the basis of clinical signs of a rheumatic disease. On the other hand, the test may give more "false" positive results among elderly patients who have a high prevalence of rheumatoid factors and antinuclear antibodies. ${ }^{26}$

Rheumatoid factor-antinuclear antibodies-enzyme immunoassay can not replace the conventional assays because it does not detect all the relevant antinuclear antibodies occurring in certain connective tissue diseases such as scleroderma and polymyositis. ${ }^{5}$ If these diseases are suspected the indirect immunofluorescence test of specific assays for antinuclear antibodies is preferred. Rheumatoid factorantinuclear antibodies-enzyme immunoassay or similar assays may be useful in the screening for autoantibody activity in smaller laboratories and also in laboratories performing large series of samples from-for example, population studies or from therapeutic trials. The addition of specific autoantigens to the test panel also makes it possible to use enzyme immunoassay for differential diagnosis of rheumatic diseases. $^{27}$

\section{References}

1 Johnson PM, Faulk WP. Rheumatoid factor: Its nature, specificity, and production in rheumatoid arthritis. Clin Immunol Immunopathol 1976;6:414-30.

2 Tan EM. Autoantibodies to nuclear antigens (ANA): their immunobiology and Medicine. Adv Immunol 1982;33:167-240.

3 Ritchie R. The clinical significance of titered antinuclear antibodies. Arthritis Rheum 1967;10:544-52.

4 Koffler D, Miller TE, Faiferman I. Antibodies to native and denatured deoxyribonucleic acid. Antipolynucleotide antibodies: the rheumatic connection. Hum Pathol 1983;14:406-18.

5 McKendry RJR, Dunne JV. A comparison of the clinical usefulness of eight tests for IgM rheumatoid factor. Am J Clin Pathol 1982;78:517-20.

6 Molden DP, Nakamura RM, Tan EM. Standardization of the immunofluorescence test for autoantibody to nuclear antigens (ANA): use of reference sera of defined autoantibody specificity. Am J Clin Pathol 1984;82:57-66.

7 Valdiserri RO, Petronie JS. ANA testing: a comparison of two kits and a discussion of specificity and sensitivity as criteria for selection of screening procedures. Am J Clin Pathol 1984;81:308-11.

8 Gripenberg $M$, Kurki P. Demonstration of human autoantibodies by quantitative enzyme immunoassays. $J$ Immunol Methods 1986;92:145-59.

9 Cohen AS, Reynolds WE, Franklin EC, et al. Preliminary criteria for the classification of systemic lupus erythematosus. Bull Rheum Dis 1971;21:643-8.

10 Ropes MW, Bennett GA, Cobb S, et al. Revision of diagnostic criteria for rheumatoid arthritis. Bull Rheum Dis 1958;9:175-80.

11 Gripenberg M, Linder E, Kurki P, Engvall E. A solid phase enzyme-linked immunosorbent assay (ELISA) for the demonstration of antibodies against denatured, single-stranded DNA in patient sera. Scand J Immunol 1978;7:151-7. 
12 Gripenberg $M$, Wafin F, Isomäki $H$, Linder E. A simple enzyme immunoassay for the demonstration of rheumatoid factor. $J$ Immunol Methods 1979;31:109-18.

13 White PJ, Gardner WD, Hoch SO. Identification of the immunogenically active components of the Sm and RNP antigens. Proc Natl Acad Sci USA 1981;78:626-30.

14 Laemmli UK. Cleavage of structural proteins during the assembly of the head of bacteriophage T4. Nature 1970;227:680-5.

15 Kurki P, Helve T, Dahl O, Virtanen I. Neurofilament antibodies in systemic lupus erythematosus. $J$ Rheumatol 1986;13:69-73.

16 Kurki P, Gripenberg M, Teppo A-M, Salaspuro M. Profiles of antinuclear antibodies in chronic active hepatitis, primary biliary cirrhosis and alcoholic liver disease. Liver 1984;4:134-8.

17 Partanen $P$, Seppänen $H$, Suni J, Vaheri A. Selective reactivity of antibodies to human immunoglobulins $\mathbf{G}, \mathbf{M}$ and $\mathbf{A}$ with rubella virus proteins. $J$ Clin Microbiol 1985;21:800-2.

18 Lange A. Evaluation of the simultaneous estimation of antidsDNA anti-ssDNA antibodies for clinical purposes. Clin Exp Immunol 1978;31:472-81.

19 Maddison PJ, Provost TT, Reichlin M. Serological findings in patients with "ANA-negative" systemic lupus erythematosus. Medicine 1981;60:87-94.

20 Boak AM, Kincaid LA, Treadwell EL, et al. Comparison of various preparations of nuclear antigens by hemagglutination inhibition (HAI). Immunol Commun 1984;13:127-36.

21 Struckmann J, Manthorpe R, Bendixen G. Anti-ENA antibody in serum determined by ELISA-technique. Allergy 1981;36:397-403.

22 Warlow $R$, Carrano J, Dawkins $R$. A rapid screening enzyme linked immunosorbent assay for antibodies to extractable nuclear antigens. Diagn Immunol 1984;2:154-60.

23 Eisenberg RA, Winfield JB, Cohen PL. Subclass restriction of anti-Sm antibodies in MRL mice. $J$ Immunol 1982;129:2146-9.

24 Teppo A-M, Gripenberg M, Kurki P, Baklien K, Helve T, Wegelius $\mathrm{O}$. Purification and characterization of a nuclear SSB antigen. Scand J Immunol 1982;15:1-7.

25 Venables PJW, Charles PJ, Buchanan RRC, et al. Quantitation and detection of isotypes of anti-SS-B antibodies by ELISA and Farr assays using affinity purified antigens. Arthritis Rheum 1983;26:146-55.

26 Goodwin JS, Searles RP, Tung KSK. Immunological responses of a healthy elderly population. Clin Exp Immunol 1982;48:403-10.

27 Gripenberg M, Helve T, Kurki P. Profiles of antibodies to histones, DNA and IgG in patients with systemic rheumatic diseases determined by ELISA. $J$ Rheum 1986;12:934-9.

Requests for reprints to: Dr P Kurki, Department of Pathology, University of Helsinki, Haartmaninkatu 3, SF-00290, Helsinki, Finland. 